REVIEW ARTICLE

\title{
A review of the development of two types of human skeletal muscle infections from microsporidia associated with pathology in invertebrates and cold-blooded vertebrates
}

\author{
Ann Cali ${ }^{1}$, Louis M. Weiss ${ }^{2,3}$ and Peter M. Takvorian ${ }^{1}$ \\ ${ }^{1}$ Department of Biologic Sciences, Rutgers University, Newark, New Jersey 07102, USA; \\ ${ }^{2}$ Department of Pathology, ${ }^{3}$ Department of Medicine, Albert Einstein College of Medicine, Bronx, New York 10461, USA
}

Key words: Pleistophora ronneafiei, Brachiola algerae, Trachipleistophora hominis, myositis in humans, water transmission

\begin{abstract}
Traditionally, the Microsporidia were primarily studied in insects and fish. There were only a few human cases of microsporidiosis reported until the advent of AIDS, when the number of human microsporidian infections dramatically increased and the importance of these new pathogens to medicine became evident. Over a dozen different kinds of microsporidia infecting humans have been reported. While some of these infections were identified in new genera (Enterocytozoon, Vittaforma), there were also infections identified from established genera such as Pleistophora and Encephalitozoon. The genus Pleistophora, originally erected for a species described from fish muscle, and the genus Encephalitozoon, originally described from disseminated infection in rabbits, suggested a link between human infections and animals. In the 1980's, three Pleistophora sp. infections were described from human skeletal muscle without life cycles presented. Subsequently, the genus Trachipleistophora was established for a human-infecting microsporidium with developmental differences from species of the genus Pleistophora. Thus, the existence of a true Pleistophora sp. or spp. in humans was put into question. We have demonstrated the life-cycle stages of the original Pleistophora sp. (Ledford et al. 1985) infection from human muscle, confirming the existence of a true Pleistophora species in humans, P. ronneafiei Cali et Takvorian, 2003, the first demonstrated in a mammalian host. Another human infection, caused by a parasite from invertebrates, was Brachiola algerae (Vavra et Undeen, 1970) Lowman, Takvorian et Cali, 2000. The developmental stages of this human muscle-infecting microsporidium demonstrate morphologically what we have also confirmed by molecular means, that $B$. algerae, the mosquito parasite, is the causative agent of this human skeletal muscle infection. $B$. algerae had previously been demonstrated in humans but only in surface infections, skin and eye. The diagnostic features of $B$. algerae and $P$. ronneafiei infections in human skeletal muscle are presented. While Encephalitozoon cuniculi has been known as both an animal (mammal) and human parasite, the idea of human microsporidial infections derived from cold-blooded vertebrates and invertebrates has only been suggested by microsporidian phylogeny based on small subunit ribosomal DNA sequences but has not been appreciated. The morphological data presented here demonstrate these relationships. Additionally, water, as a link that connects microsporidial spores in the environment to potential host organisms, is diagrammatically presented.
\end{abstract}

\section{INTRODUCTION}

Microsporidia, a protistan phylum, is currently considered most closely aligned with the fungi. All members of the phylum are obligate intracellular parasites. There are over 1,200 species in more than 140 genera. They cause infections in every major group of animals, both vertebrate and invertebrate, and more recently, because of AIDS, they have been identified as significant opportunistic parasites of man. The Microsporidia are ubiquitous parasites in the animal kingdom but, until recently, they have maintained relative anonymity because of the specialised nature of pathology researchers. Human pathologists only study infections of humans and similarly, veterinary, fishery, and invertebrate pathologists only study infections of their respective host groups. Additionally, the journals in which these researchers publish are also specialised, thus maintaining the isolation. Finally, there are only a few comparative microsporidiologists and the need for communication between all of these researchers is great. The 2004 NATO sponsored meeting brought microsporidial researchers of all types together, a necessary first step toward sharing microsporidial information among such a diverse group.

Historically, the discoveries of microsporidial infections in the animal kingdom reflect the separation of researchers. The microsporidia were first discovered in insects where they represent the majority of microsporidial diversity and the longest history of microsporidial studies. Nosema bombycis Naegeli, 1857, a parasite of

This paper was presented at the NATO Advanced Research Workshop "Emergent Pathogens in the 21st Century: First United Workshop on Microsporidia from Invertebrate and Vertebrate Hosts", held in České Budějovice, Czech Republic, July 12-15, 2004. 
silk worms, was the first microsporidium described. It was discovered because of its economic impact on the silk industry. Now there are about 70 genera described from insects and more than half are from mosquitoes, insects of medical importance (Becnel and Andreadis 1999). The history of microsporidial infections in fish began in the late 1800 's. Here again, the majority of reports were in the economically important food fish. There are about a dozen genera reported from fish, with the majority of infections from the genera Glugea Thelohan, 1891 and Pleistophora Gurley, 1893 (Canning and Lom 1986). In the 1920's, Encephalitozoon cuniculi Levaditi, Nicolau et Schoen, 1923 was described from rabbits (Levaditi et al. 1923), but it was not until the 1960's that it was accepted as being a microsporidial organism (Lainson et al. 1964, Weiser 1964) and not until 1970 that Encephalitozoon was made a microsporidial genus (Cali 1970). Now there are over 30 known hosts and E. cuniculi almost exclusively dominates (Canning and Lom 1986, Cali and Owen 1988).

In 1976, a very brief chapter on microsporidiosis (Strano et al. 1976) was included in a two-volume atlas of human infectious diseases. This chapter included one disseminated infection illustrated with light and electron micrographs of biopsy tissue, a corneal disc eye infection, and two possible "Encephalitozoon-like" infections. Thus there were very few reports before the 1980's, when because of AIDS, microsporidia were established as opportunistic parasites of man (Cali and Owen 1988, Cali 1991). They are now known to cause clinical disease in any immunosuppressive situation and have also been reported in immunocompetent individuals. Enterocytozoon and Encephalitozoon are the genera that are most often reported but about a dozen different genera and species of microsporidia have been identified (Wittner and Weiss 1999) and they may infect virtually any tissue or organ (Orenstein et al. 1997).

Most of the microsporidia described have been discovered because of their impact on economically important hosts. While human disease caused by microsporidia has the most recent history, it is their medical importance that has brought them into the spotlight. This in combination with modern biotechnology has revealed more about microsporidial biology in the past 15-20 years than was known from all the prior years.

Spores are the diagnostic feature for the phylum Microsporidia. With all their developmental diversity, the spore morphology is the one unifying feature. These spores are small, resistant to environmental conditions, and possess a unique germination process. Each spore contains a polar filament which everts, producing a long hollow polar tube and a sporoplasm that travels through it, inoculated into a potential host cell in a manner similar to a syringe needle inoculation and resulting in the initiation of the intracellular developmental cycle (Cali and Takvorian 1999).
The spores of the microsporidia are the key structure for identification into the phylum (Cali and Takvorian 1999, Vávra and Larsson 1999). They are also the key to their success because spores provide many important survival features. They provide an ability to survive outside the host, some spores survive many years in water (Cali and Takvorian, 2004), an ability to get from one host to another (spores exit in body waste products or from decomposed hosts into the environment), an ability to gain entry into potential hosts by direct contact (on food or in water), and an ability to germinate, enter cells and cause infection. These abilities have enabled some microsporidia to bridge major host groups.

Some microsporidia infect both animals and humans. Encephalitozoon cuniculi was first reported in mammals and has dominated the warm-blooded animal infections so it was expected to occur in humans although this was not demonstrated until the mid 1980's (Terada et al. 1987). Other human-infecting microsporidia, such as Enterocytozoon bieneusi Desportes et al., 1985 were first discovered in humans (Desportes et al. 1985) and have subsequently been demonstrated in other mammals (Dengjel et al. 2001, Sulaiman et al. 2003). These shared infections were expected and are not discussed here. The focus of this report is on examples of microsporidia that infect both non-mammalian animals and man.

The microsporidia associated with insect or fish infections were not expected to cause human infections but some do. Two such examples are presented here. The genus Pleistophora, known only to infect coldblooded vertebrates, fish, and possibly invertebrates (Canning and Lom 1986, Becnel and Andreadis 1999) and Brachiola algerae, a mosquito parasite (Vavra and Undeen 1970), will be illustrated as the causative agents in human disease. Biopsies of skeletal muscle tissues presented below were collected from two immunecompromised patients with myositis.

\section{PLEISTOPHORA RONNEAFIEI}

The biopsies used for the Pleistophora identification were from muscle tissues obtained in 1984 from a severely immunodeficient male with generalized muscle weakness and contractures (Ledford et al. 1985, Macher et al. 1988). Biopsies from the left quadriceps and left deltoid were fixed in $10 \%$ neutral buffered formalin and processed for light microscopy. Subsequently, some of this tissue was reprocessed for electron microscopy (EM) by removal of paraffin, rehydration and postfixation in $1 \%$ osmium tetroxide. These tissues were embedded in Epon, thin sectioned, stained with uranyl acetate and lead citrate, and examined on a Philips TEM at the Rutgers-Newark microscopy facility.

The tissue blocks from the Ledford et al. (1985) case examined by EM contained clusters of organisms in parasite-secreted envelopes within the cytoplasm of striated muscle cells (Fig. 1). The early stages of the 
parasite development are each surrounded by parasitesecreted dense material that forms a honey comb-like vesicular network. These secretion envelopes are most elaborate in the proliferative phase of the parasite development. The proliferative cells range from small oneto-four-nucleate cells to large multinucleate plasmodial cells containing about a dozen nuclei in a single plane of section. The nuclei in these cells are never in diplokaryotic arrangement. These cells were observed in various stages of cytokinesis with the plasmalemmal secretions remaining attached to the cell surface and dividing with it (Fig. 2). The commencement of sporogony is morphologically indicated by the plasmalemma retraction from the secretion envelope (Figs. 3, 4) and the diminution of vesiculation of the surrounding secretions, now forming the sporophorous vesicle (SPOV). The cell inside this envelope is a large multinucleate plasmodium, now known as a sporogonial plasmodium. Subsequently, several cell divisions occur inside SPOV (Figs. 5, 6) resulting in the formation of many single-nucleate cells, sporoblasts (Fig. 7), which each develop into a spore (Fig. 8). The result is a homogeneously thick-walled vesicle containing many spores. The single-nucleate spores measured 3.3-4 $\times 2-2.8 \mu \mathrm{m}$ and they contained 9 to 11 polar filament cross-sections in a single row.

\section{BRACHIOLA ALGERAE}

The muscle biopsies containing Brachiola algerae were from a 57-year-old woman who was given immunosuppressive drugs for years for treatment of rheumatoid arthritis. The woman presented with a six-week history of increasing fatigue, generalized muscle and joint pain, profound weakness, and fever. Musclebiopsy specimens were taken from the left and right quadriceps muscles (Coyle et al. 2004). Tissue samples were processed for light and electron microscopy (EM). Tissues processed for light microscopy were fixed in $10 \%$ neutral buffered formalin, embedded in paraffin sectioned, and stained with haematoxylin and eosin,
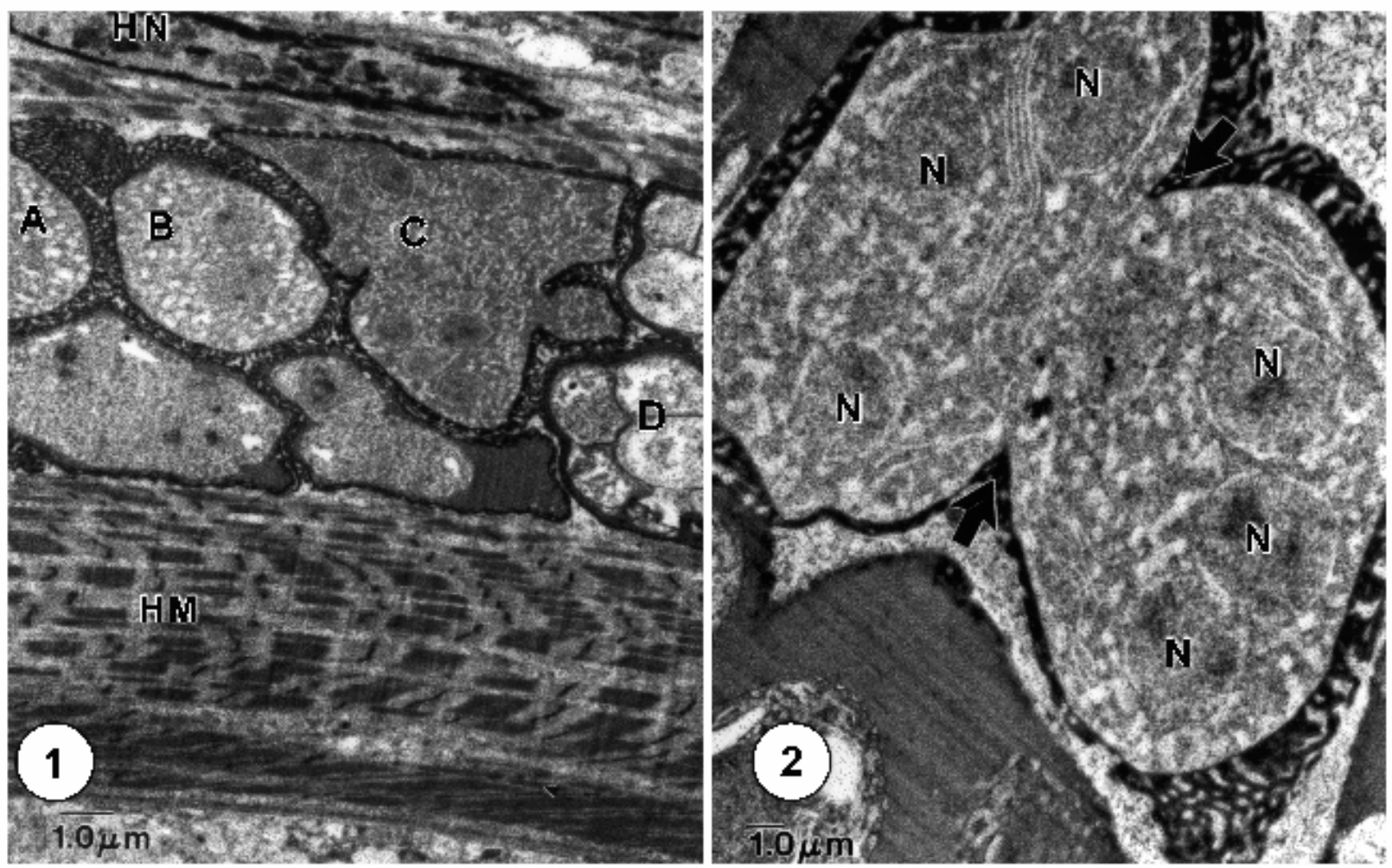

Figs. 1, 2. Developmental stages (A, B, C, D) of Pleistophora ronneafiei in human skeletal muscle. Fig. 1. Low-power micrograph demonstrating the location of the infection, abutting bundles of actin and myosin filaments arranged as normal, functional contractile units of host muscle (HM) and containing a host cell nucleus (HN). The parasite early stages are each surrounded by an elaborate network of parasite-secreted dense material. The vesicle wall is most elaborate in proliferative development as illustrated between proliferative cells A, B and C. The proliferative cells A and B are probably sister cells as in early proliferative development the cells divide with the secretions. Later, the proliferative cells undergo several karyokinetic divisions without cytokinesis, resulting in the formation of large proliferative plasmodial cells (C). In sporogony, multiple parasite cells (cluster D) may be found within each sporophorous vesicle, which appears more homogeneously dense in sporogony. Fig. 2. Dividing proliferative plasmodium of Pleistophora ronneafiei in human skeletal muscle. Proliferative plasmodium, containing six nuclei (N) in plane of section, is undergoing cytokinesis. Note the dense secretions present on the invaginating plasmalemma (arrows). The secretion material divides with the proliferative plasmodial cell. 


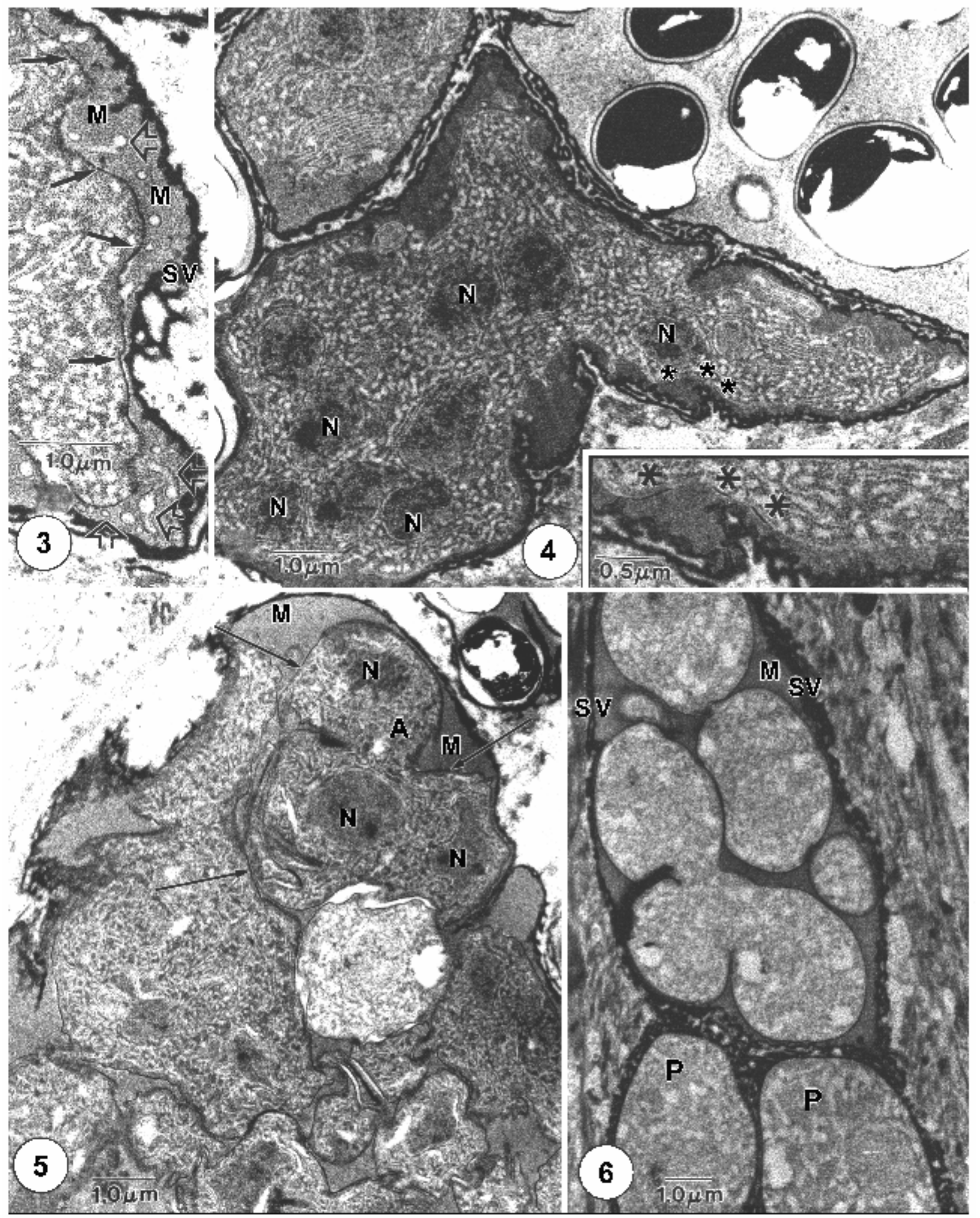

Figs. 3, 4. Early sporogonial activity in Pleistophora ronneafiei. Elaborate secretion network present during proliferative development looses most of the vesiculation during early sporogony in human skeletal muscle. Fig. 3. Early sporont. The plasmalemma has just started to separate (arrows) from the sporophorous vesicle wall, which has already become less vesicular and more densely coated with the dense secretions. Note the presence of tubules (open arrowheads) in the matrix (M) between the plasmalemma and the sporophorous vesicle wall (SV). Fig. 4. Early sporont. The plasmalemma has pulled away from the vesicle wall and has begun to invaginate starting the plasmodial division process. Note the presence of many nuclei $(\mathrm{N})$ in the plasmodium and the beginning of plasmalemmal thickening in small patches $(*)$ along its surface. Insert is enlargement of membrane 

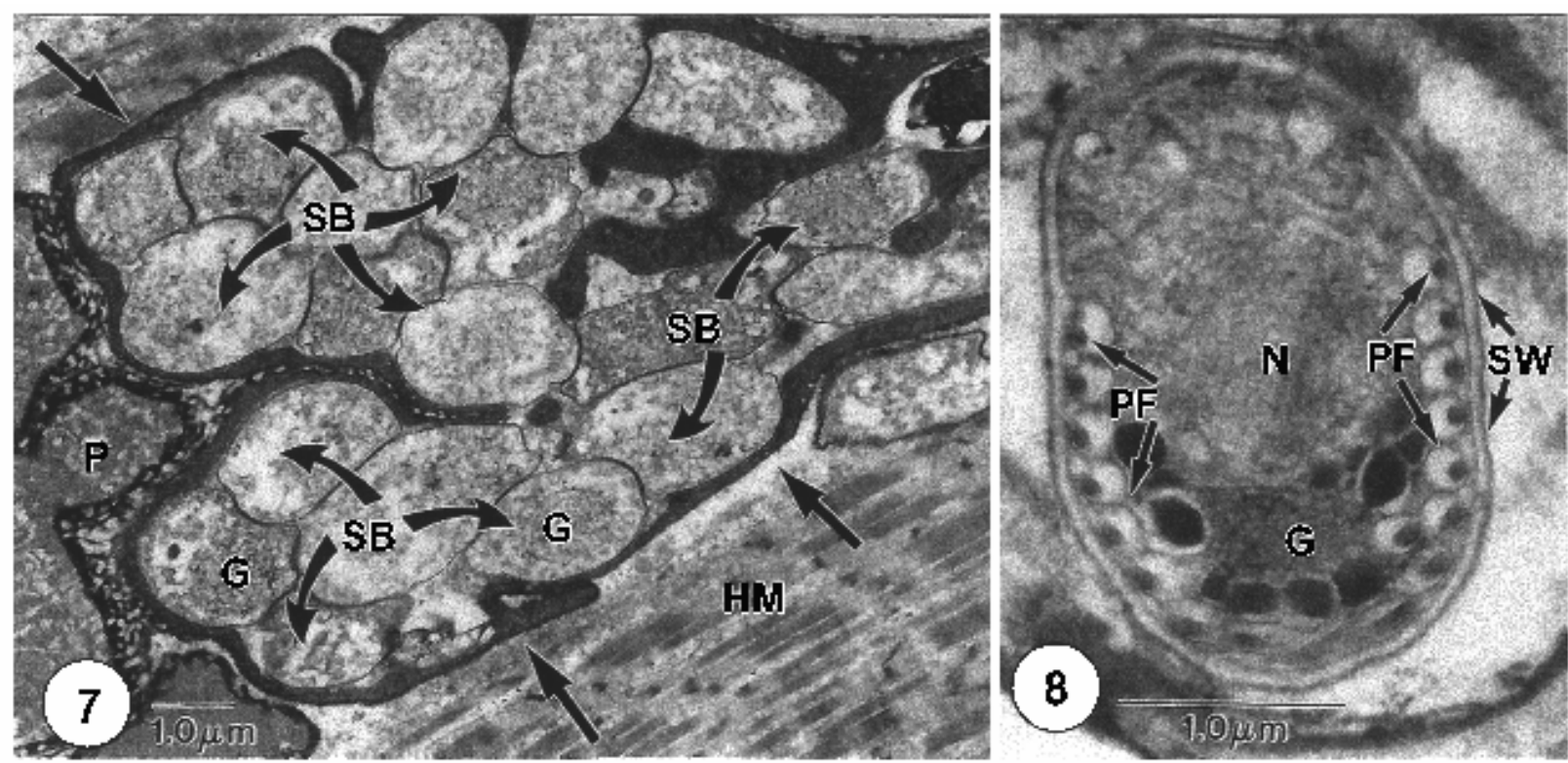

Figs. 7, 8. Sporoblasts and early spore of Pleistophora ronneafiei in human skeletal muscle. Fig. 7. After sporogonial plasmotomy is completed, the sporophorous vesicle is filled with many uninucleate cells, the sporoblasts (SB), some with the Golgi complex (G) visible. The sporophorous vesicle containing many early sporoblasts (SB) is produced by a polysporous sporogony process. This sporophorous vesicle is abutted to a proliferative plasmodium (P). Note the difference in projections on vesicle walls (straight arrows). The vesicle walls prevent the parasite cells from having direct contact with the host muscle cytoplasm (HM). Fig. 8. Late sporoblast or early spore contains a single nucleus (N), the developing polar filament (PF), the Golgi complex (G), and the beginning of spore wall (SW) thickening. (Figs. 1-8 reprinted with permission from Cali and Takvorian 2003.)

according to standard techniques. Biopsy tissues for EM were fixed in $0.1 \mathrm{M}$ cacodylate-buffered $2.5 \%$ glutaraldehyde and then processed according to standard methods (Cali et al. 1998). The samples were examined with the use of a Tecnai 12 transmission electron microscope at the Rutgers-Newark electron microscopy facility.

The muscle tissue blocks from the Coyle et al. (2004) patient revealed a very different morphology. When haematoxylin and eosin-stained biopsy slides were viewed with light microscopy, large masses of spores in direct contact with the host cell cytoplasm were seen in the otherwise pink muscle cell cytoplasm (Fig. 9). EM was necessary to observe the parasite developmental pattern (Figs. 10-14). This infection, also in the cytoplasm of the muscle cells, consisted of many individual small cells and spores in direct contact with the host cell cytoplasm, each containing diplokaryotic nuclei. The electron-dense plasmalemma of the proliferative cells had secretions on their cell surfaces that took several forms from blister-like structures or ridges on the plasmalemma (Fig. 10) to more vesiculotubular structures that sometimes extended into the host cell cytoplasm (Fig. 11), but no protoplasmic extensions were ob- served. The cells appear to have karyokinesis and cytokinesis linked as they usually each contained a single diplokaryon. Sporogony was characterized by the detachment of most of the vesiculotubular structures from the plasmalemmal surface resulting in a more homogeneous electron-dense cell surface (Fig. 12). Two sporoblasts were produced from each sporont. The sporoblasts contained a single diplokaryon, the beginnings of polar filament formation, and a generally denser cytoplasm (Fig. 13). The spores averaged $4 \times 2 \mu \mathrm{m}$ with 8 12 coils of polar filament arranged in a single row (Fig. 14).

\section{DISCUSSION}

Clinical manifestations of human microsporidial infections with Pleistophora spp. (Ledford et al. 1985, Chupp et al. 1993, Grau et al. 1996) and Brachiola spp. (Cali et al. 1998, Cali et al. 2003, Coyle et al. 2004) include muscle infections resulting in severe myositis or death. The two cases presented here are discussed separately.

area with thickening $\left(^{*}\right)$. Figs. 5, 6. Sporogonial cell division of $P$. ronneafiei in human skeletal muscle. Fig. 5. The plasmodium, in its sporophorous vesicle, divides serially, producing smaller multinucleate daughter cells and ultimately many single-nucleate cells. Multinucleate plasmodial division in a homogeneous matrix (M). The plasmalemma is retracting from the sporophorous vesicle wall. Plasmodial cytokinesis has commenced and the plasmalemma is already completely thickened (arrows). The sporogonial plasmodium has undergone a few cell divisions; the cell (A) is dividing into three cells, each containing one nucleus (N) and all with thickened membranes (arrows). Note the loss of branching of the sporophorous vesicle wall as compared to cells A, $\mathrm{B}$, and C in Fig. 1. Fig. 6. A sporophorous vesicle (SV) containing a cell dividing into at least three cells surrounded by a homogenous matrix $(\mathrm{M})$. There are two proliferative cells $(\mathrm{P})$ abutting the sporophorous vesicle. 


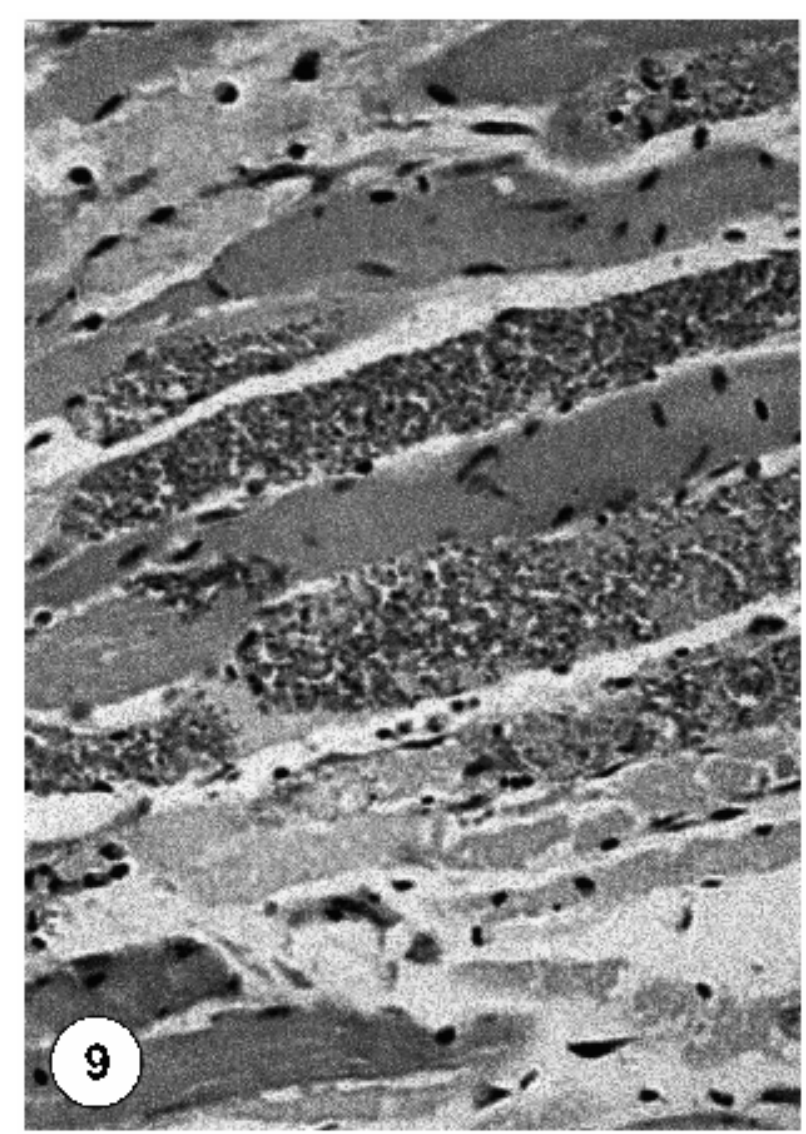

Fig. 9. Light micrograph of Brachiola algerae infection in human skeletal muscle. Stained tissue reveals multiple organisms in the muscle fibres (arrows). Haematoxylin and eosin, $\times 1,000$. (Reprinted with permission from Coyle et al. 2004.)

\section{Pleistophora ronneafiei}

Comparisons of the organism reported by Ledford et al. (1985) as Pleistophora sp. to the type species for the genus Pleistophora and to the type species for the genus Trachipleistophora were necessary to demonstrate the affiliation with the genus Pleistophora. Pleistophora typicalis Gurley, 1893 is the type species for the genus Pleistophora. It was originally found in skeletal muscle in the fish, Myoxocephalus scorpius (Gurley 1893). Since that time, many species of Pleistophora have been described. Canning and Nicholas (1980) amended the characteristics of Pleistophora on the basis of ultrastructural findings made on the type species. Their description includes a proliferative phase with plasmodia that divide producing smaller plasmodia. The plasmalemma of these cells is coated with a dense layer of secretions that divides along with the cells. The plasmalemma retracts from the dense coat and thickens at the onset of sporogony, resulting in the formation of a SPOV containing the sporogonial plasmodium. Sporogony is polysporous, occurring by stepwise division of the sporogonial plasmodium from multinucleate segments into uninucleate sporoblasts, which undergo metamorphosis into mature spores, all within the dense coat known as the sporophorous vesicle.

In 1996, a new microsporidium was identified in human skeletal muscle that was similar to Pleistophora but did not form multinucleate plasmodia in the sporogonic phase of development. The genus Trachipleistophora Hollister, Canning, Weidner, Field, Kench, et Marriott, 1996, was erected for this human infection (Hollister et al. 1996). The taxonomically significant features of Trachipleistophora hominis from Hollister et al. (1996) include uninucleate sporonts that retract their plasmalemma within their surface coat, which becomes the envelope of the sporophorous vesicle. Within the vesicle, a series of binary fissions of binucleate stages produce uninucleate sporoblasts and spores. Multinucleate sporogonial plasmodia are not formed. The features of the sporogonic phase of the genus Trachipleistophora represent the taxonomically significant differences between it and the genus Pleistophora (Hollister et al. 1996, Cali and Takvorian 2003).

On the basis of these descriptions of type organisms of the two genera in question, it is clear that the causative agent in the human microsporidiosis case, originally reported by Ledford et al. (1985), belongs in the genus Pleistophora because it forms the multinucleate sporogonial plasmodia (Figs. 3-6) characteristic of Pleistophora and absent in Trachipleistophora. It has been named $P$. ronneafiei (Cali and Takvorian 2003) and represents the first documented case of a true Pleistophora infection to occur in a warm-blooded host, a human.

\section{Brachiola algerae}

This case was originally reported by Coyle et al. (2004). It represents a host variation, from an invertebrate host to a human. When this organism was first observed, it was thought that it would be the species for which the genus Brachiola was established. The genus Brachiola Cali, Takvorian et Weiss, 1998 was originally established for a human-infecting microsporidium, $B$. vesicularum (Cali et al. 1998). It is in the family Nosematidae because these parasites share several characteristics including nuclei in diplokaryotic arrangement throughout the life cycle, multiplication by simple fission of elongated cells, no plasmodial stages, all parasite stages are in direct contact with host cytoplasm, development is disporoblastic, and sporonts produce two diplokaryotic spores. Uniquely, in the genus Brachiola, all stages are covered with electron-dense secretions (precocious thickened plasmalemma) and a variety of plasmalemmal ornamentations including various forms of appendages which may be on the cell surface or attached to protoplasmic extensions. These structures usually dissociate from the parasite cell surface during sporogony, resulting in very few of them on the spores and the remnants scattered all around the parasite cells inside the host cell cytoplasm. Physiologically, 

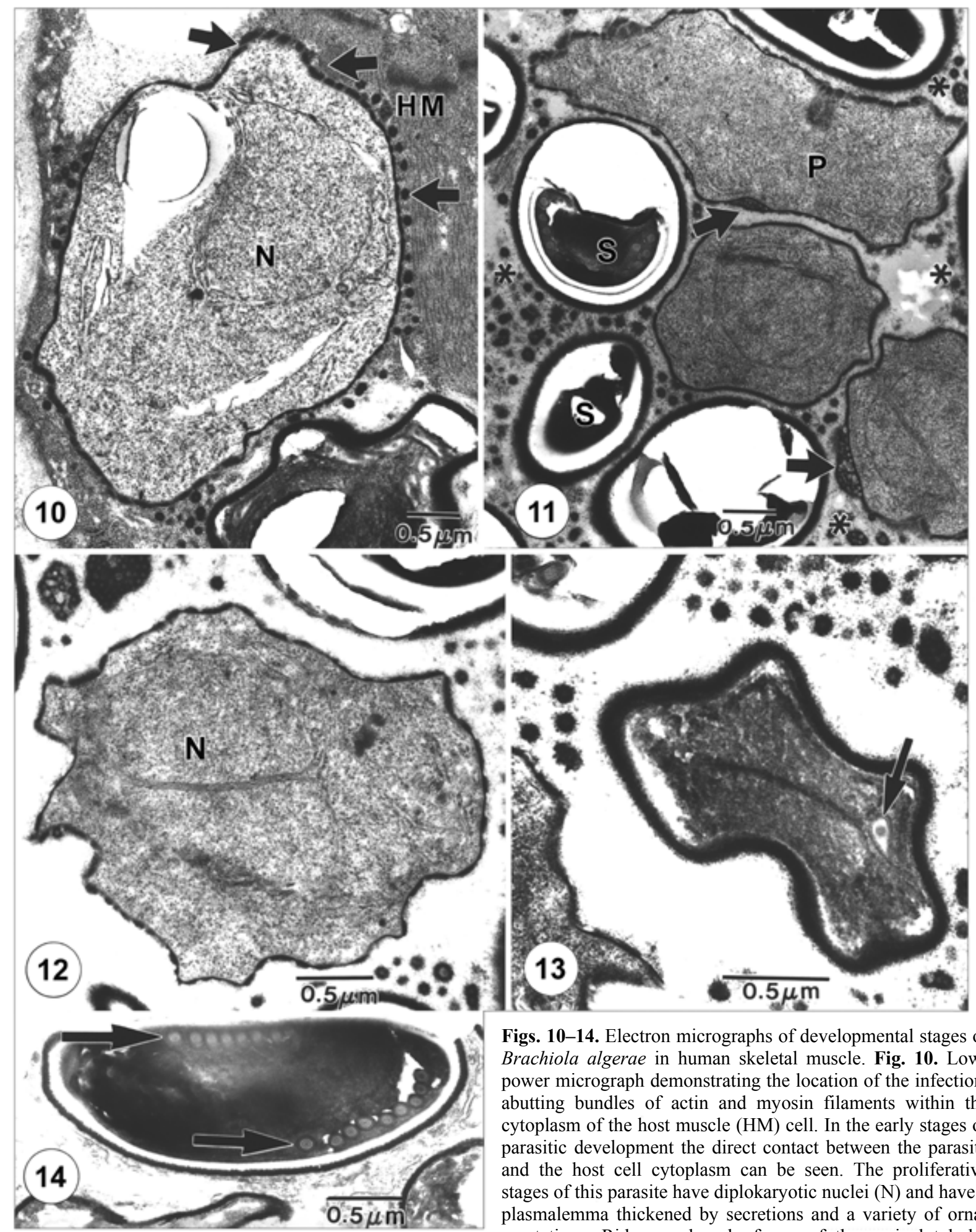

Figs. 10-14. Electron micrographs of developmental stages of Brachiola algerae in human skeletal muscle. Fig. 10. Lowpower micrograph demonstrating the location of the infection, abutting bundles of actin and myosin filaments within the cytoplasm of the host muscle (HM) cell. In the early stages of parasitic development the direct contact between the parasite and the host cell cytoplasm can be seen. The proliferative stages of this parasite have diplokaryotic nuclei $(\mathrm{N})$ and have a plasmalemma thickened by secretions and a variety of ornamentations. Ridges and early forms of the vesiculotubular appendages are present (arrows). Fig. 11. Parasite development is asynchronous, thus spores (S) and proliferative stages (P) are intermixed. The vesiculotubular appendages are present both free in the host cytoplasm $\left({ }^{*}\right)$ as dense particulate masses and attached to the plasmalemma of proliferative cells (arrows). Fig. 12. Early diplokaryotic (N) sporont cell. Appendages have detached, their remnants are in the surrounding area, the plasmalemma is still irregularly thickened. Fig. 13. Diplokaryotic sporoblast. These cells are characterized by the very thick electron-dense homogenous surface coat, dense cytoplasm diplokaryotic nuclei and the early stages of polar filament formation (arrow). The crenated shape is also characteristic as they resist fixation and shrink away from the surrounding material. Fig. 14. Mature spore containing nine polar filament cross-sections (arrow) arranged in a single row. (Original micrographs, not previously published.) 

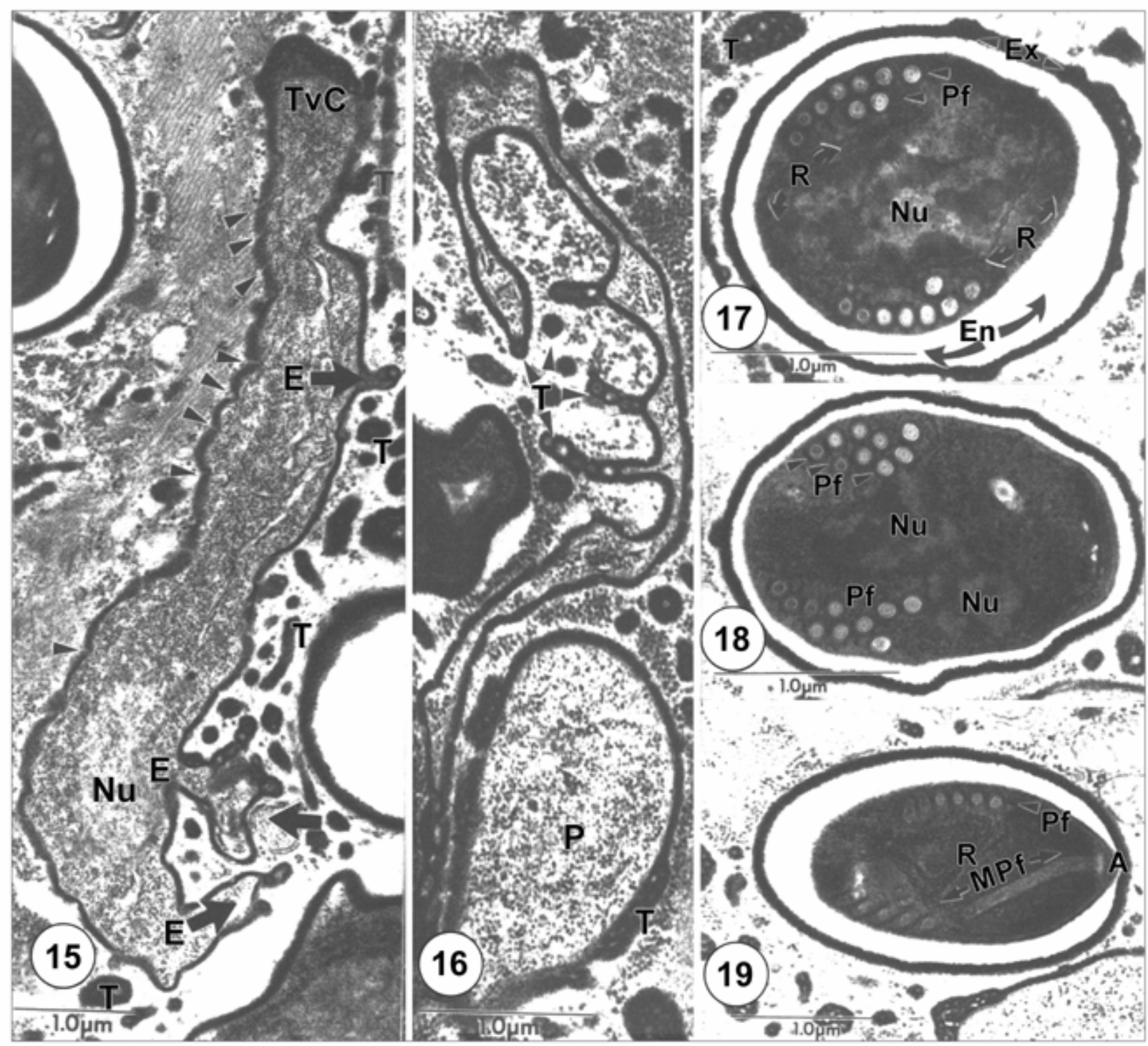

Figs. 15-19. Brachiola vesicularum from human skeletal muscle biopsy. Protoplasmic extensions and a variable polar filament. Fig. 15. Proliferative cell with three protoplasmic extensions (E) projecting from the cell (arrows). Vesiculotubular appendages $(\mathrm{T})$ associated with nucleated $(\mathrm{Nu})$ elongated cell and protoplasmic extensions; vesiculotubular complex (TvC) at end of elongated cell. The thickened plasmalemma has the typical ridged or scalloped appearance (arrowheads). Fig. 16. Example of elaborate nature of protoplasmic extensions with associated vesiculotubular appendages $(T)$. Note close proximity to a typical proliferative cell (P). Fig. 17. Section through spore, illustrating the most common polar filament arrangement observed: nine crosssections of an anisofilar polar filament (Pf) coil arranged in two rows with two to three narrower-diameter cross-sections. Spore structures include dense accumulations of ribosomes $(\mathrm{R})$, nuclei $(\mathrm{Nu})$, electron-lucent endospore (En), electron-dense exospore (Ex) with some appendage material still attached. Fig. 18. Spore containing ten polar filament (Pf) cross-sections clustered into three rows (arrowheads). Fig. 19. Section through anterior anchoring disc (A) complex of the polar filament (Pf), illustrating its anterior manubroid (MPf) portion and the cross-sections arranged in a single row. Note the presence of ribosomal clusters (R) in the sporoplasm. (Reprinted with permission from Cali et al. 1998.)

Brachiola species are thermophilic, proliferating and sporulating at temperatures $\geq 37^{\circ} \mathrm{C}$ (Cali et al. 1998). The type species, $B$. vesicularum from a human skeletal muscle infection, additionally forms structures described as protoplasmic extensions (Figs. 15, 16). These structures extend from elongated proliferative cells and resemble "arms" or branches off the main body of the cell. They are extremely elongated, extending great distances from the main cell body, and possess the vesicu- lotubular structures seen on the surface of the parasite cells. These protoplasmic extensions are unique among the microsporidia. The spores are ovoid, 2.5-2.9 $\times 1.9$ $2.0 \mu \mathrm{m}$ but typically $2.9 \times 2.0 \mu \mathrm{m}$ in size. The polar filament forms $7-10$ coils with a variable arrangement (Figs. 17-19). It is typically observed as nine crosssections in two rows but one and three rows also occur (Cali et al. 1998). 


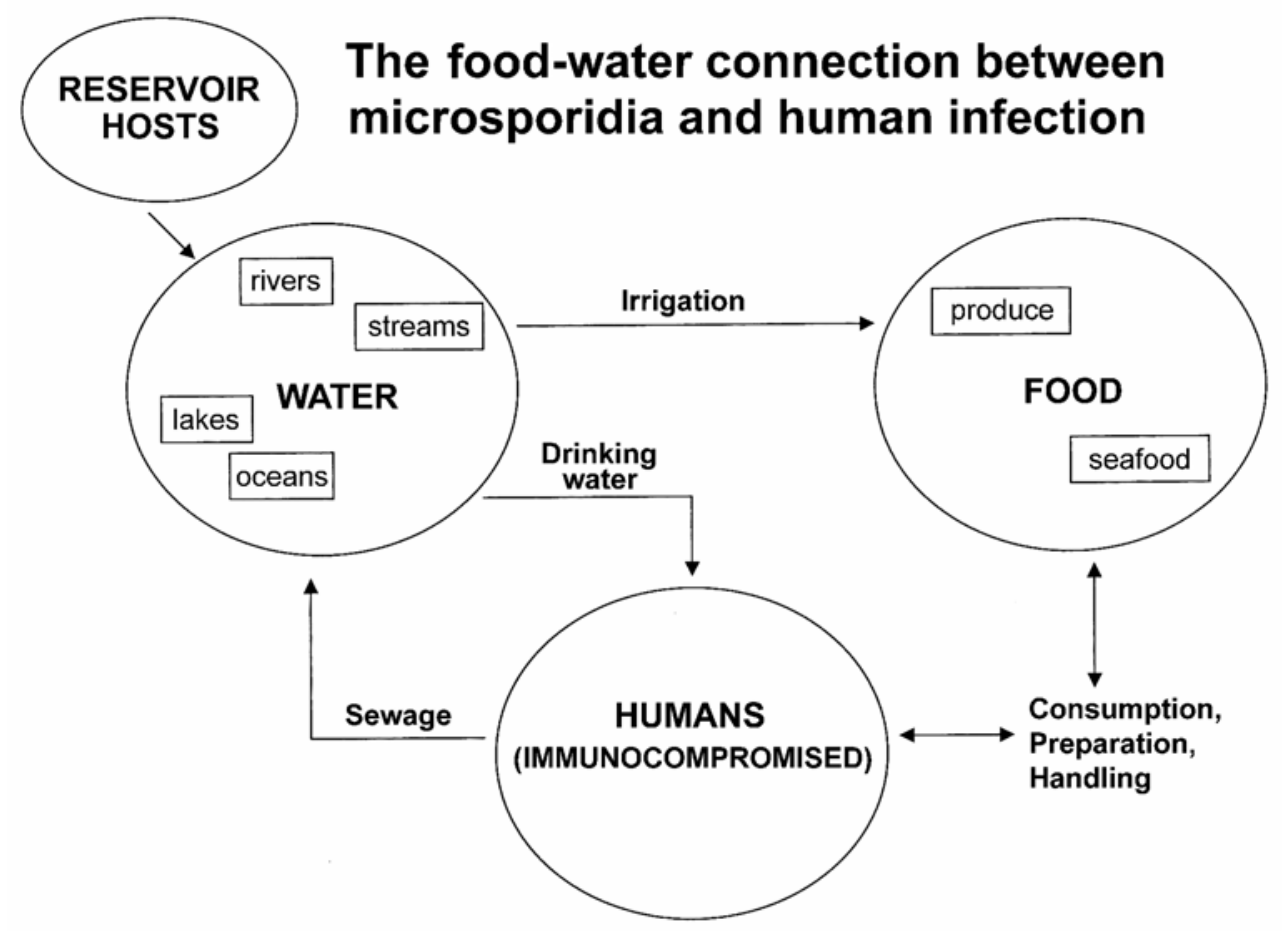

Fig. 20. A diagram illustrating how water connects humans, animals, and food, with microsporidial spores. Its no wonder that these spores have evolved to survive best in a water environment, it presents several probable routes for human exposure to the spores. (Reprinted with permission from Cali and Takvorian 2004.)

It was initially thought that the new biopsy tissue (Coyle et al. 2004) contained B. vesicularum, the human-infecting parasite, since there were diplokaryotic stages in direct contact with the host cell cytoplasm. The parasite proliferative stages had the cell surface thickening, vesiculotubular appendages, ridges, and "blisters" as well as the sporogonic appendage remnants scattered around the parasite cells in host cytoplasm (Figs. 10, 11), however, closer examination revealed a lack of protoplasmic extensions, a larger spore size $(4 \times 2 \mu \mathrm{m})$, and a polar filament arrangement (typically single row) consistent with $B$. algerae (Fig. 14), originally described in mosquitoes (Vavra and Undeen 1970, Avery and Anthony 1983). Additionally, since $B$. algerae sequence data were available, this biopsy material was molecularly proven to be $B$. algerae (Coyle et al. 2004). This parasite had already been demonstrated in association with human infection but only with body surface infections, ocular and skin epithelium (Visvesvara et al. 1999), and that isolate has been experimentally grown in SCID mice (Koudela et al. 2001). The case presented here, however, represents the first deep tissue infection with B. algerae in a human (Cali et al. 2004, Coyle et al. 2004).

It is probable that these two examples of microsporidia infecting both humans and lower animals, are not the only ones, and microsporidian phylogeny based on small subunit ribosomal DNA sequences supports this theory (Baker et al. 1995, Weiss and Vossbrinck 1999). Humans probably come in contact with microsporidial spores from many sources, including food, other humans, pets, and the most probable source, water. The one most common denominator for microsporidial spore contact is water (Cali and Takvorian 2004). As was stated earlier, water provides the environment for the greatest spore survival rates, spores in waste products or sewage end up in water (Dowd et al. 1998, Thurston-Enriquez et al. 2002) and water is consumed for drinking and irrigation of our foods, including those we eat raw (Fournier et al. 2000, ThurstonEnriquez et al. 2002). Water can contaminate our hands, get into our eyes, onto our foods or be consumed directly. Water is the one universal connection for all living organisms (Fig. 20). Humans who are immunesuppressed need to be mindful of the water and/or raw products they consume. Pathologists need to be aware of the microsporidia across the animal kingdom.

Acknowledgements. We would like to acknowledge Ms. Cyrilla Pau for technical assistance with the preparation of this material, Ms. Lynn Garcia for e-mailing a light micrograph of the Brachiola case to the attention of one of us (AC), and Drs. Rhodes and Coyle for providing the Brachiola tissue samples. This research was supported by NIH grant no. AI52035. 


\section{REFERENCES}

AVERY S.W., ANTHONY D.W. 1983: Ultrastructural study of early development of Nosema algerae in Anopheles albimanus. J. Invertebr. Pathol. 42: 87-95.

BAKER M.D., VOSSBRINCK C.R., DIDIER E.S., MADDOX J.V., SHADDUCK J.A. 1995: Small subunit ribosomal DNA phylogeny of various microsporidia with emphasis on AIDS related forms. J. Eukaryot. Microbiol. 42: $564-570$

BECNEL J.J., ANDREADIS T.G. 1999: Microsporidia in insects. In: M. Wittner and L.M. Weiss (Eds.), The Microsporidia and Microsporidiosis. ASM Press, Washington, D.C., pp. 447-501.

CALI A. 1970: Morphogenesis in the genus Nosema. Proc. IV Intl. Colloq. Insect Pathol., College Park, MD., pp. 431438.

CALI A. 1991: General microsporidian features and recent findings on AIDS isolates. J. Protozool. 38: 625-630.

CALI A., COYLE C., TAKVORIAN P.M., WITTNER M., RHODES L.V., BROWN D., NAKTIN J., YOUND E., COLASANT G., WEISS L.M. 2003: Preliminary evidence for Brachiola algerae as the etiology of a case of myositis. VIII International Workshops on Opportunistic Protists (IWOP-8) and International Conference on Anaerobic Protists (ICAP). Hilo, HI, U.S., July, 2003.

CALI A., OWEN R.L. 1988: Microsporidiosis. In: A. Balows et al. (Eds.), Laboratory Diagnosis of Infectious Diseases, Principles and Practice. Springer-Verlag, New York, pp. 929-950.

CALI A., TAKVORIAN P.M. 1999: Developmental morphology and life cycles of the Microsporidia. In: M. Wittner and L.M. Weiss (Eds.), The Microsporidia and Microsporidiosis. ASM Press, Washington, D.C., pp. 85-128.

CALI A., TAKVORIAN P.M. 2003: Ultrastructure and development of Pleistophora ronneafiei n. sp., a microsporidium (Protista) in the skeletal muscle of an immunecompromised individual. J. Eukaryot. Microbiol. 50: 7785.

CALI A., TAKVORIAN P.M. 2004: The Microsporidia: pathology in man and occurrence in nature. S. E. Asian J. Trop. Med. Public Health 35 (Suppl.): 58-64.

CALI A., TAKVORIAN P.M., LEWIN S., RENDEL M., SIAN C.S., WITTNER M., TANOWITZ H.B., KEOHANE E., WEISS L.M. 1998: Brachiola vesicularum, n. g., n. sp., a new microsporidium associated with AIDS and myositis. J. Eukaryot. Microbiol. 45: 240-251.

CALI A., WEISS L.M., TAKVORIAN P.M. 2004: An analysis of the microsporidial genus Brachiola, with comparisons of human and insect isolates of $B$. algerae. J. Eukaryot. Microbiol. 51: 678-685.

CANNING E.U., NICHOLAS J.P. 1980: Genus Pleistophora (Phylum Microspora): redescription of the type species, Pleistophora typicalis Gurley, 1893 and ultrastructural characterization of the genus. J. Fish Dis. 3: 317-338.

CANNING E.U., LOM J. 1986: The Microsporidia of Vertebrates. Academic Press, London, 289 pp.

CHUPP G.L., ALROY J., ADELMAN L.S., BREEN J.C., SKOLNIK P.R. 1993: Myositis due to Pleistophora (Mi- crosporidia) in a patient with AIDS. Clin. Infect. Dis. 16: $15-21$.

COYLE C.M., WEISS L.M., RHODES L.V., CALI A., TAKVORIAN P.M., BROWN D.F., VISVESVARA G.S., XIAO L.H., NAKTIN J., YOUNG E., GARECA M., COLASANTE G., WITTNER M. 2004: Fatal myositis due to the microsporidian Brachiola algerae, a mosquito pathogen. N. Engl. J. Med. 351: 42-47.

DENGJEL B., ZAHLER M., HERMANNS W., HEINRITZI K., SPILLMANN T., THOMSCHKE A., LOSCHER T., GOTHE R., RINDER H. 2001. Zoonotic potential of Enterocytozoon bieneusi. J. Clin. Microbiol. 39: 4495-4499.

DESPORTES I., LE CHARPENTIER Y., GALIAN A., BERNARD F., COCHAND-PRIOLLET B., LAVERGNE A., RAVISSE F., MODIGLIANI R. 1985: Occurrence of a new microsporidian: Enterocytozoon bieneusi n. g., $\mathrm{n}$. sp., in the enterocytes of a human patient with AIDS. J. Protozool. 32: 250-245.

DOWD S.E., GERBA C.P., PEPPER I.L. 1998: Confirmation of the human-pathogenic microsporidia Enterocytozoon bieneusi, Encephalitozoon intestinalis, and Vittaforma corneae in water. Appl. Environ. Microbiol. 64: 33323335.

ENRIQUEZ F.J., TAREN D., CRUZLOPEZ A., MURAMOTO M., PALTING J.D., CRUZ P. 1998: Prevalence of intestinal encephalitozoonosis in Mexico. Clin. Infect. Dis. 26: $1227-1229$.

FOURNIER S.D., LIGUORY S.O., GAUSSIN F., SANTILLANA-HAYAT M., SARFATI C., MOLINA J.-M., DEROUIN F. 2002: Detection of microsporidia, cryptosporidia and giardia in swimming pools: a one-year prospective study. FEMS Immunol. Med. Microbiol. 33: 209213.

GRAU A., VALLS M.E., WILLIAMS J.E., ELLIS D.S., MUNTANE M.J., NADAL C. 1996: Miositis por Pleistophora en un paciente con sida. Med. Clin. (Barc.) 107: 779-781.

GURLEY R. 1893: On the classification of the myxosporidia, a group of protozoan parasites infecting fishes. Bull. U.S. Fish. Comm. 11: 407-420.

HOLLISTER W.S., CANNING E.U., WEIDNER E., FIELD A.S., KENCH J., MARRIOTT D.J. 1996: Development and ultrastructure of Trachipleistophora hominis n.g., n.sp. after in vitro isolation from an AIDS patient and inoculation into athymic mice. Parasitology 112: 143-154.

KOUDELA B., VISVESVARA G.S., MOURA H., VÁVRA J. 2001: The human isolate of Brachiola algerae (Phylum Microspora): development in SCID mice and description of its fine structure features. Parasitology 123: 153-162.

LAINSON R., GARNHAM P.C.C., KILLICK-KENDRICK R., BIRD R.G. 1964: Nosematosis, a microsporidial infection of rodents and other animals, including man. Brit. Med. J. 2: 470-472.

LEDFORD D.K., OVERMAN M.D., GONZALVO A., CALI A., MESTER S.W., LOCKEY R.F. 1985: Microsporidiosis myositis in a patient with the acquired immunodeficiency syndrome. Ann. Intern. Med. 102: 628-630. 
LEVADITI C., NICOLAU S., SCHOEN R. 1923: L'agent étiologique de l'encéphalite épizootique du lapin (Encephalitozoon cuniculi). C. R. Soc. Biol. Paris 89: 984986.

LOWMAN P.M., TAKVORIAN P.M., CALI A. 2000: The effects of elevated temperature and various timetemperature combinations on the development of $\mathrm{Bra}$ chiola (Nosema) algerae n. comb. in mammalian cell culture. J. Eukaryot. Microbiol. 47: 221-234.

MACHER A.M., NEAFIE R., ANGRITT P., TUUR S.M., NELSON R.P., CALI A. 1988: AIDS. Case for diagnosis series, 1988. Military Med. 153: M41-M48.

ORENSTEIN J.M., GAETZ H.P., YACHNIS A.T., FRANKEL S.S., MERTENS R.B., DIDIER E.S. 1997: Disseminated microsporidiosis in AIDS - are any organs spared. AIDS 11: 385-386.

STRANO A.J., CALI A., NEAFIE R.C. 1976: Microsporidiosis. In: Pathology of Tropical and Extraordinary Diseases - An Atlas. Vol. 1. Armed Forces Institute of Pathology, Washington, D.C., pp. 336-339.

SULAIMAN I.M., FAYER R., LAL A.A., TROUT J.M., SCHAEFER F.W., XIAO L.H. 2003: Molecular characterization of microsporidia indicates that wild mammals harbor host-adapted Enterocytozoon spp. as well as human-pathogenic Enterocytozoon bieneusi. Appl. Environ. Microbiol. 69: 4495-4501.

TERADA S., REDDY K., JEFFERS L.J., CALI A., SCHIFF E.R. 1987: Microsporidan hepatitis in the acquired immunodeficiency syndrome. Ann. Intern. Med. 107: 61-62.
THURSTON-ENRIQUEZ J.A., WATT P., DOWD S.E., ENRIQUEZ R., PEPPER I.L., GERBA C.P. 2002: Detection of protozoan parasites and microsporidia in irrigation waters used for crop production. J. Food Prot. 65: 378382.

VAVRA J., UNDEEN A.H. 1970: Nosema algerae n. sp. (Cnidospora, Microsporida) a pathogen in a laboratory colony of Anopheles stephensi Liston (Diptera, Culicidae). J. Protozool. 17: 240-249.

VÁVRA J., LARSSON J.I.R. 1999: Structure of the Microsporidia. In: M. Wittner and L.M. Weiss (Eds.), The Microsporidia and Microsporidiosis. ASM Press, Washington, D.C., pp. 7-84.

VISVESVARA G.S., BELLOSO M., MOURA H., DA SILVA A., MOURA I., LEITCH G., SCHWARTZ D.A., CHEVEZ-BARRIOS P., WALLACE S., PIENIAZEK N.J., GOOSEY J. 1999: Isolation of Nosema algerae from the cornea of an immunocompetent patient. J. Eukaryot. Microbiol. 46: 10S.

WEISS L.M., VOSSBRINCK C.R. 1999: Molecular biology, molecular phylogeny, and molecular diagnostic approaches to the Microsporidia. In: M. Wittner and L.M. Weiss (Eds.), The Microsporidia and Microsporidiosis. ASM Press, Washington, D.C., pp. 85-128.

WEISER J. 1964: On the taxonomic position of the genus Encephalitozoon Levaditi, Nicolau and Schoen, 1923 (Protozoa: Microsporidia). Parasitology 54: 749-751.

WITTNER M., WEISS L.M. 1999: The Microsporidia and Microsporidiosis. 1 Ed. American Society for Microbiology Press, Washington, D.C., 553 pp.

Accepted 15 January 2005 